DOI: 10.1515/auseur-2016-0007

\title{
On Linguistic Abilities, Multilingualism, and Linguistic Justice
}

\author{
Gabriele IANNÀCCARO \\ University of Stockholm \\ Vittorio DELL'AQUILA \\ Centre d'Études Linguistiques pour l'Europe \\ viorayli@gmail.com
}

\begin{abstract}
The notion of linguistic justice should be related to the concept of linguistic ease, by which we mean the full social and communicative freedom of concern of the speaker in a given social interaction involving the use of language(s) present in the society, according to the social norms of use. To acquire an acceptable degree of linguistic ease, the knowledge of at least one L2 is considered important. But the acquisition of a L2 is interfered by the previous linguistic skills of the learner/speaker who, in many cases, does not have a suitable competence even of the languages of the society in which he/she lives.
\end{abstract}

Keywords: linguistic justice, language ease, CEFR, multilingualism, diglossia

1. The notion of linguistic justice is becoming increasingly important in the scientific debate (for a complete and recent overview, see Alcalde 2015). Lately, the idea has been gaining ground that defining a linguistic environment as 'just' should not only mean that people have equal access to public resources across the world but also that a less uneven distribution of linguistic abilities should be pursued (Skutnabb-Kangas-Phillipson 1995, Phillipson 2003, Fiedler 2010, Iannàccaro-Gobbo-Dell'Aquila forthcoming). This draws our attention to the concept of linguistic ease, by which we mean the full social and communicative freedom of concern of the speaker in a given social interaction involving the use of language(s), for example in different communicative situations like chatting with friends in a pub or talking with teachers during lessons or in front of a civil servant. In every society, as we know, different varieties are used, and their use is ruled by binding sociolinguistic norms (see at least Ammon-Dittmar-MattheierTrudgill 2006/2008). In monolingual communities, we define these varieties as 
registers of the same language, whilst in multilingual settings the varieties - even structurally quite different from one another - receive a specific name by the speakers themselves (like 'dialects', 'languages', 'patois', and so forth).

Now, it is self-evident that a 'just' linguistic society should ensure such kind of ease at least in the relationships between speakers and institutions (Wickström 2013, Gazzola 2014): undoubtedly, interactions among individual speakers are outside the scope of a democratic linguistic policy. In Europe, a three-faceted competence is usually regarded as a balanced one: a fully competent EU citizen should master (1) her/his local variety, where it exists, (2) the national language, and (3) a L2 as the international code (implicitly English); also some observers consider the mastery of a fourth 'election' L2 desirable. Of course, all these languages must be acquired either spontaneously or by means of formal education.

As for the linguistic acquisition, institutions are not usually interested in the acquisition of (1), which is mainly left to families and peer groups, while (2) is typically the concern of the nation-states' educational institutions (Gazzola 2006). The 'real' L2 acquisition, while still factually under the control of nation-states through their school systems, is more and more the interest of the EU, at least for what concerns the frameworks of reference for linguistic competence and certifications and guidelines to achieve the learning goals. European institutions, for instance, show particular attention to the 6-level scale of L2 acquisition, from A1 to C2 (CEFR 2011). Ideally, reaching C2 level in a given acquired L2 would ensure a complete linguistic ease in any situation requiring the use of that language.

But if we now turn to situations of language acquisition different from the 'classical' prestigious L2 acquisition, and consider - admittedly, with a forced reading of the parameters - also formal L1 acquisition, we suspect that reaching a C2 level is not only depending upon the mere knowledge of a given language but also on a general capacity of verbal expression at large. In this case, acquiring a complete linguistic ease can be an issue for L1 too, and it can pose interesting questions of linguistic justice. If we take, for instance, the average European situation, we can suppose that, in a number of cases at least, level C2 is not acquired even by a number of individuals that are normally considered 'mother tongue' speakers. In fact, a person who

can understand with ease virtually everything heard or read. Can summarise information from different spoken and written sources, reconstructing arguments and accounts in a coherent presentation. Can express him/herself spontaneously, very fluently and precisely, differentiating finer shades of meaning even in more complex situations (CEFR 2011: 24),

as stated in the declaration for level C2, is a highly educated person who masters high skills in dealing with complex (socio)linguistic situations. However, not all 
European citizens - as for our experience - can read with ease all types of texts in their language of education, for instance. Nor can they deal - even orally with all possible communicative settings. To understand 'with ease' a given text (oral or written), to 'express [...] spontaneously, very fluently and precisely', and especially to 'summarise information from different spoken and written sources' in formal and difficult (linguistic) situations requires a cultural skill which is not easy to acquire. This skill is related to a set of factors, the first one being the level of formal education reached by the speaker. This implies that the structure and the functioning of the educational system is one of the main issues that governs the achievement of the highest linguistic/communicative levels, independently from the language of tuition.

According to Eurostat, more than half of the EU's population does not reach the Upper Secondary Education level (European Qualifications Framework Level 4), with figures ranging from the Czech Republic - 31\% - to Portugal - 77\% - (2013): we can imagine that this high percentage of population does not feel at ease in every linguistic situation, not even in their mother tongue (or at least the language in which they received their formal education). Other factors are nonetheless equally important: the traditional level of complexity of the formal or bureaucratic language in use and the degree of social acceptance of linguistic deviance (commonly called 'mistakes'). Languages like French, Italian, English, or German show a quite high internal variation between everyday (written) language and 'formal jargons' such as the language of a number of newspapers, the language of the political discourse or of medical reports, and especially the language of legal or bureaucratic texts. A compulsory schooling, in most cases, is not enough to achieve a full communicative competence in whatever language (Beacco et alii 2010).

2. So much for speech communities which, with a simplification, we have previously defined as monolingual: in fact, in many parts of Europe (and as a norm in the world), society is characterized by the use of more than one code (i.e. languages, dialects, patois, and so forth), even structurally quite different from each other, at the same time in the same community - and these codes necessarily show functional specializations. We are, of course, not referring to the rare and maybe hypothetical cases of societal bilingualism, in which all the members of the community can speak and use two languages for all verbal communicative purposes and situations, but to what is broadly known as diglossia and/or dilalia (Ferguson 1959, Berruto 1995, Dell'Aquila-Iannàccaro 2004). With these two terms, we mean - here we will not take into consideration the rather important differences between the two notions - all the actual social situations of functional differentiation between at least a high-status and high-function code and a lowfunction code. In a diglossic situation, such as in German-speaking Switzerland 
(where there is one code which is written and nearly only written, Hochdeutsch, and another which is spoken and nearly only spoken, Schwytzertütsch/Dialekt), in North Africa (Classical Arabic / Standard Arabic / regional Arabics), or in many parts of Italy (Italian / Romance varieties), and so on, the actual competence of a speaker can be split, in other words, distributed among different languages. An average speaker may well have different levels of competence in different codes, and this imbalance can be tolerated or even fostered by the repertory norms of the speech community. In Zürich, for instance, no member of the speech community is expected to write the very code she/he speaks, in nearly no occasion, but, for example, in jokes or very informal texts, mainly in form of chat or phone messages: a 'just' and perfect linguistic competence here means acquiring different levels in different codes, more or less like:

\begin{tabular}{ccc}
\hline & Spoken & Written \\
\hline Schwytzertütsch & C2 & - \\
\hline Hochdeutsch & B1 (> C2) & C2 \\
\hline
\end{tabular}

The point is that while in a monolingual society the same level of competence is required for all communicative skills of one language (with a conscious knowledge of the social rules that underlie the use of language registers), here the abilities are distributed among the codes: and it is 'just' for this community that the members do not reach the highest level in every single code of the repertoire - rather they should acquire a split general communicative ability.

Now, it is obvious that CEFR levels are meant as goals to achieve in learning a specific L2, and not as a description of complex sociolinguistic situation; nonetheless, it is noteworthy that such a view presupposes linguistic communities in which all the known languages reach the highest levels (the cell 9) in the well-known Kloss's model (Kloss 1952, Darquennes 2005). In reality, not all the codes shared by a given speech community react in the same way, as to their position in Kloss's model, nor is this considered as desirable by the community. The asymmetry, quite evident in terms of multilingual speakers' linguistic competence, has interesting consequences for the acquisition of a second language: learning, even perfectly, (standard) Arabic or German does not assure the ease in dealing with mother tongue speakers of these languages - at least, in many real situations. At the same time, being perfectly at ease with their spoken counterparts only, maybe as a result of informal acquisition, poses problems of formal communication, and opens the door to severe linguistic unease. 
3. In dealing with linguistic justice, then, we would like to draw researchers' attention to these two simple points:

a) Real speech communities are often multilingual and have well-defined social norms that control coexistence and the alternation of codes in different linguistic situations. Habits, competences, and the speakers' will, deriving from fine-grain understanding of the relationships between the codes in their speech community, should not be forgotten or neglected.

b) Before inserting elements of (further) multilingualism in any speech community, it is vital to strengthen communicative competence, absolute expressiveness, culture, and metalinguistic awareness at large within the members of the community. This is a prerequisite to be acquired, starting from any language of the speaker, preferably from the strongest at her/his disposal. Every L2 acquisition policy - in order to master a prestigious international L2 and 'justly' accede to more societal and intellectual resources - should start in the form of acquisition of more refined skills in any language, and only thereafter in the target one. An L2 acquisition policy that does not take into consideration the possible lack of linguistic communicative skills of the target population can run the risk of not reaching a higher level of linguistic justice but, on the contrary, of increasing the gap between the highly educated population (being then able to communicate in L1 and L2) and the less educated population, thus not reaching a suitable degree of language competence in any language.

\section{References}

ALCALDE, Javier 2015. Linguistic Justice: An Interdisciplinary Overview of the Literature. A'dam Multiling 3: 27-96.

AMMON, Ulich-DITTMAR, Norbert-MATTHEIER, Klaus J.-TRUDGILL, Peter. 2006/2008. Sociolinguistics/ Soziolinguistik. An International Handbook of the Science of Language and Society/ Ein internationales Handbuch zur Wissenschaft von Sprache und Gesellschaft. II ed. vol. 3. Berlin-New York: Mouton de Gruyter.

BEACCO, Jean-Claude-BYRAM, Michael-CAVALLI, Marisa-COSTE, DanielEGLI CUENAT, Mirjam-GOULLIER, Francis-PANTHIER, Johanna. 2010. Guide for the Development and Implementation of Curricula for Plurilingual and Intercultural Education. Strasbourg: Language Policy Division, Council of Europe.

BERRUTO, Gaetano. 1995. Fondamenti di sociolinguistica. Bari: Laterza.

CEFR: Council of Europe. 2011. Common European Framework of Reference for Languages: Learning, Teaching, Assessment. www.coe.int. 
DARQUENNES, Jeroen. 2005. Sprachrevitalisierung aus kontaktlinguistischer Sicht. Theorie und Praxis am Beispiel Altbelgien-Süd. St. Augustin: Asgard.

DELL'AQUILA, Vittorio-IANNÀCCARO, Gabriele. 2004. La pianificazione linguistica. Lingue, società, istituzioni. Roma: Carocci.

FERGUSON, Charles A. 1959. Diglossia. Word 15: 325-340.

FIEDLER, Sabine. 2010. Approaches to Fair Linguistic Communication. European Journal of Language Policy 2(1): 1-22.

GAZZOLA, Michele. 2006. Managing Multilingualism in the European Union: Language Policy Evaluation for the European Parliament. Language Policy 5(4): 393-417.

2014. Lingva justeco: Kiel taksi ĝin? La ekzemplo de Eŭropa Unio. In: VERGARA, José Antonio (ed.), Aktoj De La Internacia Kongresa Universitato, 67a Sesio. Rotterdam: Universala Esperanto-Asocio.: 74-89.

IANNÀCCARO, Gabriele-GOBBO, Federico-DELL'AQUILA, Vittorio. forthcoming. The Assessment of Sociolinguistic Justice: Parameters and Models of Analysis. In: WICKSTRÖM, Bengt-Arne-GAZZOLA, Michele (eds), Language Policy and Linguistic Justice: Economic, Philosophical and Sociolinguistic Approaches. Berlin-Heidelberg-New York: Springer.

KLOSS, Heinz. 1952. Die Entwicklung neuer germanischer Kultursprachen seit 1800. München: Pohl.

PHILLIPSON, Robert. 2003. English-Only Europe. Challenging Language Policy. London: Routledge.

SKUTNABB-KANGAS, Tove-PHILLIPSON, Robert. 1995. Linguistic Human Rights: Overcoming Linguistic Discrimination. Berlin: Mouton de Gruyter.

WICKSTRÖM, Bengt-Arne. 2013. The Optimal Babel: An Economic Framework for the Analysis of Dynamic Language Rights. In: CABRILLO, FranciscoPUCHADES-NAVARRO, Miguel A. (eds), Constitutional Economics \& Public Institutions: Essays in Honour of José Casas-Pardo. Cheltenham: Edward Elgar: 322-344. 